\title{
Ability to Learn Indonesian Language Through Online Zoom Application System in SMP Negeri 14 Medan
}

\author{
Rosmilan Pulungan $1^{1)}$, Hermawati Syarif ${ }^{2)}$ \\ ${ }^{1)}$ Universitas Muslim Nusantara Al-Washliyah, ${ }^{2)}$ Universitas Negeri Padang \\ email: rosmilanpulungan@umnaw.ac.id ${ }^{1}$, hermawati_sy@yahoo.com ${ }^{2}$
}

\begin{abstract}
Indonesia is currently faced with the challenge of the Covid-19 pandemic, in which the government urges the Indonesian people to stay at home. So that learning activities that were originally carried out face-toface turned into non-face-to-face learning. This study uses descriptive research methods with qualitative analysis techniques. The purpose of this research is to reveal events or facts, circumstances, phenomena, variables and circumstances that occurred during the research by presenting what actually happened. This study uses descriptive research methods with qualitative analysis techniques. The instrument in this study was a questionnaire that was proposed to the sample. With a total of 20 questions, each question is given a score of 5 so that the highest score in this test is 100. The results of this study are the implementation of online learning in class VIII AD SMP Negeri 14 Medan is less effective, especially in learning Indonesian, because in the implementation of online learning students only given the task of working on evaluation questions and only occasionally practice, and the teacher does not know whether the students really understand or not. Considering that students study at home accompanied by their parents or guardians, it is possible that students' assignments are assisted by their parents or guardians.
\end{abstract}

Keywords: Zoom Meeting Application, Pandemic COVID-19, E-learning

\section{Introduction}

Indonesia is currently faced with the challenge of the Covid-19 pandemic, in which the government urges the Indonesian people to stay at home. The Covid-19 pandemic has not only affected the economic and social sectors, but also the education sector, which now inevitably has to start adapting to this era. So that learning activities that were originally carried out face-to-face turned into non-face-to-face learning. The program is known as online learning or the E-learning system or online learning. According to Isman (2016: 587) online learning is the use of the internet network in the learning process. Online in the Big Indonesian Dictionary (KBBI) means in a network, connected through a computer network, the internet. So online learning is an effort to teach students which is done without face-to-face through the available network/internet.

The implementation of online learning by the government requires all teaching and learning activities to be carried out from home. The implementation of online learning is carried out as an effort to continue to realize education in Indonesia in the midst of the Covid-19 pandemic, as well as efforts to prevent the spread of the Covid-19 virus. The Covid-19 pandemic has forced the learning system in schools to drastically change from face-to-face meetings to online learning. The implementation of this learning takes place from junior high school to university level.

In education units at the level of SMP Negeri 14 Medan, the implementation of online learning is still relatively rare and has never been implemented. So that the application of online learning in junior high school will definitely encounter various obstacles. Changes in learning habits are the most significant obstacle during the pandemic. Initially, this learning process was enthusiastically received by 
students because the learning was carried out at home. However, learning becomes boring because you do the same routine every day. In addition, the intensity of the teacher in delivering a material in one of the subjects is less than optimal. Teachers who usually use the lecture method will have difficulty in online learning, but it is different from teachers who use other methods. So that in the implementation of online learning which is still relatively new, of course there will be obstacles faced by teachers, students and schools.

Negative impacts can be caused if online learning is carried out by relying on assignments without explaining the material. Because in a learning situation like this, teachers are required to be more active in understanding how to communicate with students with distinctly different languages and tools. The use of learning methods and online learning media must be chosen appropriately for learning. online during the pandemic can be done optimally. This is because the COVID-19 pandemic has not shown an end. Therefore, the development of children's learning will depend on the process of teaching and learning activities, and the development of children's learning at home will tend to be different from the development of learning at school so that teachers as facilitators must have various innovations, provide motivation to students in carrying out teaching and learning activities.

\section{Methods}

The design of this research is all the processes carried out in the planning and implementation of a research, as for the working methods used to achieve the suggestions and objectives that have been formulated. This study uses descriptive research methods with qualitative analysis techniques. The purpose of this research is to reveal events or facts, circumstances, phenomena, variables and circumstances that occurred during the research by presenting what actually happened. Sutopo (2016) in Bogdan (2014: 4) defines it as one that leads to detailed and in-depth descriptions of both conditions and processes, as well as the relationship or interrelationships regarding the main things found in the research objectives and can even understand the actions on the subject and object under study through techniques such as in-depth interviews and documentation. Because to get results from in-depth research on the analysis of online learning in Indonesian language learning, it would be better if it was done with interviews and documentation.

Research instrument is a tool used to collect data. To obtain the data required a tool called a research instrument. The instrument in this study was a questionnaire, namely "Indonesian Language Learning Skills Through the Zoom Online Application System at SMP Negeri 14 Medan." Which is submitted on the sample. With a total of 20 questions, each question is given a score of 5 so that the highest score in this test is 100 .

The steps for Data Collection Techniques are as follows: (1) explain what the Zoom Application is in learning at school; (2) explain what is Indonesian language learning ability according to the KBBI. Data collection is one of the activities supporting the implementation of research activities, where data collection is carried out to determine the success or failure of a research. The data collection procedures used by the research include: (1) Interview. interviews in this study were used to determine the Analysis of Indonesian Language Learning Ability Through the Zoom Online Application System at SMP Negeri 14 Medan Class VIII for the 2020-2021 Academic Year. (2) Documentation. In this study, internal documentation is in the form of a description of the profile of the school under study, facilities and infrastructure, educators and education staff, the number of students, to an overview of the placement of SMP Negeri 14 Medan. While external documentation is in the form of reference books, journals related to previous research techniques, books sourced from the internet and books. (3) Questions Method. This method is used to obtain data or information from respondents by providing a written list of questions. (4) Observation Method. Observations were carried out by researchers by observing and recording the results of interviews conducted with the sample. 
The researcher uses the data analysis method from Miles, Huberman \& Saldana (2014) which is called the term Interactive model, this technique consists of three components, namely data reduction (data reduction), data display (data display), and drawing and verifying conclusions (drawing and verifying conclusion) (Pawito, 2017: 104).

\section{Result and Discussion}

Based on the data obtained from the results of interviews with teachers in the field of study stated: From the analysis of the data that I have researched, it can be like "Distance Learning (DL) with two methods, namely the Online Learning Method (Online/Online), the Off-Network Learning Method (Offline), and the Combination Learning Method between Online and Offline. Likewise with UPT. A public junior high school that uses the three DL learning methods" (interview on June 24, 2021, at 10.30 at school) In addition, Vera as a class VIII AC teacher stated that: "Online learning is very enthusiastic because these students can experience from the previous one" (interview on June 24, 2021, 10:30 a.m. at school).

The advantages and disadvantages of learning Indonesian through the Zoom Online Application System The advantages of online learning are:

1. Students do not depend on the teacher. If usually at school students always rely on teachers to ask about things they don't know, then with this online learning students can learn or ask parents or the internet.

2. More effective in terms of place and time. Students can study more relaxed from home, are not in a rush to go to school, and students have more time to study at home. This is in accordance with the opinion of Empy and Zhuang (in Mutia and Leonard, 2013: 282) about the advantages of E-learning, namely (a) reducing costs. By using E-learning, we save time and money to reach a place of learning. With E-learning we can access from various locations and places. (b) Flexibility of time, place and speed of learning. By using E-learning, teachers can determine the time to study anywhere. And students can learn according to their respective abilities. In contrast to learning in the classroom, where all students must study and stop at the same time.

3. Increase students' self-confidence. Because learning is done online, shy students will be more confident, because they only look at the camera/hand phone.

In addition to several advantages in implementing online learning, here are:

Lack of implementation

Learning Indonesian with the Zoom Online Application System, including:

1. Signal/connection. Lack of connection signal can be from conditions or weather such as heavy rain and added if it's lightning then the signal will become more or less stable or the network is bad. Because this signal/connection is the most important factor in online learning, if there is no signal/connection then students are constrained in downloading the assignments given by the teacher and sending their learning results.

2. Teachers cannot interact directly. When implementing online learning, the teacher does not know the real progress of students. Because in the process the teacher only gives assignments, then students give feedback in the form of answers or learning outcomes. So the teacher does not know whether the student really understands or not.

In the opinion of Efendi (in Putra, 2020: 3), he expressed the shortcomings of using E-learning, including:

1. Face-to-face interactions that occur between students and teachers or between students and students are minimal.

2. The learning carried out tends to be training rather than education.

3. Business or commercial aspects become more developed than social and academic aspects. 
DOI: https://doi.org/10.24036/icolp.v1i1.40

4. Teachers are required to master learning techniques using technology, information and communication (ICT).

5. The internet facilities are not evenly distributed in places where there are problems with electricity, telephones and computers.

6. Human resources who have the expertise to operate computers are still lacking

7. Computer language that has not been mastered

8. Feelings of isolation can occur in students

9. There is variation in the quality and accuracy of information, therefore guidance is needed when answering questions.

10. Difficulty accessing images and videos because the equipment used does not support it, causing students to become frustrated.

Areas to improve for online learning to run better. So the improvements given so that the implementation of online learning is better are:

1. Increased teacher creativity. In this era, teachers are required to be more creative, especially in using media, methods, or learning strategies. In the implementation of online learning, teachers can create learning media that make it easier for students to understand the material presented by the teacher, for example power point shows, mind maps, or video explanations directly from the teacher.

2. Conduct face-to-face learning three times a week. Due to the Covid-19 pandemic, the government recommends shifting conventional learning to online, but it is better if online learning is accompanied by learning three times a week by paying attention to several things including, the school area is a safe zone or green zone, and still adheres to health protocols., and actually get permission from various parties. By conducting face-to-face learning three times for one week, teachers can use it to evaluate students, so that teachers know the progress of students during online learning.

During the Covid-19 pandemic, learning is carried out in two ways, online and offline, for the provision of material starting at $13.00 \mathrm{WIB}$ until $15.00 \mathrm{WIB}$, but for collecting assignments, students are given 1 week to complete the task even if their parents or parents are at home every day.

In this study, I can see that there are advantages and disadvantages in implementing Indonesian language learning through the Zoom Online Application system at SMP Negeri 14 Medan class VIII, including the following:

Excess :

1. Effective in distance learning because it can reach students even from a distance

2. Can do face-to-face learning instead of face-to-face learning at school

3. Can carry out learning communication in large numbers of people

Lack:

1. the problem of the absence of learning devices that do not support the Zoom application, both cellphones and laptops/computers

2. Constraints of adequate internet packages for the Zoom application

3. Knowledge constraints in using the features in the Zoom app

4. Short and limited time in the free (unpaid) Zoom app

From the results of the research that I have researched at the SMP Negeri 14 Medan, with the discussion that I have concluded from the SMP Negeri 14 school, the learning is easier and more practical and there are even several learning systems such as examples for using the Zoom Online application system, Google Classrom, Chat Via WhatsApp Group, even from Conference Zoom etc. However, only a few applications that I use to learn. So that these students can find out from some of these learning 
systems, it is even easier for students to learn even though they study remotely from school to home and children can gather with parents and parents can monitor the child in learning as well as students do not depend on the teacher and students will be more effective in all areas.

In this study, it can be seen how the Implementation of Indonesian Language Learning Through the Zoom Online Application System in SMP Negeri 14 class VIII is in very good implementation with the learning can run well but if the weather is not supportive then the learning cannot run well even the explanation given has been conveyed by the teacher will be disjointed.

Analysis of Indonesian Language Learning Ability Through the Zoom Online Application System at SMP Negeri 14 Medan Class VIII

According to Sardiman (2011), ability analysis is a change in energy in a person which is marked by the emergence of thoughts and is preceded by a response to the existence of goals, the success of an interaction process between students and with teachers in educational situations to achieve learning goals. In learning, it can be seen from student activities during learning, student responses to learning and mastery of student concepts. To achieve an effective and efficient learning concept, there needs to be a reciprocal relationship between students and teachers to achieve a common goal, besides that it must also be adapted to the conditions of the school environment, facilities and infrastructure, as well as learning media needed to help achieve all aspects of development. student.

The implementation of online learning in class VIII AD SMP Negeri 14 Medan is less effective, especially in learning Indonesian, because in the implementation of online learning students are only given the task of doing evaluation questions and only occasionally practice, and the teacher does not know whether students really understand or not. Considering that students study at home accompanied by their parents or guardians, it is possible that students' assignments are assisted by their parents or guardians.

\section{Conclusion}

This research activity has provided insight and experience to researchers in the analysis of Indonesian language learning skills through the Zoom Online application at SMP Negeri 14 Medan Class VIII for the 2020-2021 Academic Year. The conclusions from this research are:

1. Learning Indonesian through the Zoom Online Application System for Class VIII. In practice, students are only given tasks by the teacher, and give answers to the teacher so that the teacher can find out whether the students understand or not. Assignments from the teacher are usually only in the form of orders to do assignments from so many pages to so many pages and only occasionally practice.

2. Implementation of Indonesian Language Learning Through the Zoom Online Application System Class VIII trains students not to depend on teachers, students can seek answers from their curiosity from other parties such as parents, friends, relatives or from the internet. Online learning can also raise students' self-confidence, if students are usually shy to tell stories in front of the class, in online learning students want to send their videos telling stories to the teacher, but it is possible that there are students who are embarrassed when dealing with cameras/mobile phones. Apart from these advantages, In fact, there are many obstacles faced when learning online, for example, the internet network is not evenly distributed and internet access is expensive. Under these circumstances or weather conditions, it can cause connections between each other and the network/connection/signal is the main problem. A stable network is very necessary in the online learning process, because sending assignments in the form of photos, videos or audio requires a sufficient connection. The student assessment system is carried out every day, students are given a time limit of up to 1 week to submit their answers/study results, if it exceeds the specified time limit, the student is considered not doing the assignment. 
3. In the implementation of learning, teachers should use learning media that make it easier for students to understand the material so that learning remains stable even though it is carried out online. Teachers can make Power Points in learning that are as interesting as possible, using slides which students are very interested in, besides that the teacher can also create a mind map which contains the core material to be delivered by the teacher, can be made pictures or use power point.

\section{References}

Basrowi \& Suwandi. (2008). Memahami penelitian kualitatif. Jakarta: Rineka Cipta.

Hasan, M. \& Iqbal. (2019). Pokok-pokok materi metodologi penelitian aplikasinya. Jakarta: Ghalia Indonesia.

Isman, M. (2016). Pembelajaran media dan jaringan (moda jaringan). The Progressive and Fun Education Seminar.586.

Miles, M.B, Huberman, A.M, \& Saldana, J. (2014). Qualitative Data Analysis, A Methods Sourcebook, Edition 3. USA: Sage Publications. Terjemahan Tjetjep Rohindi Rohidi, UI-Press.

Mutia, I. \& Leonard. (2013). Kajian Penerapan E-Learning dalam Proses Pembelajaran di Perguruan Tinggi. Faktor Exacta 6 (4):278-289, 2013.

Pawito. (2007). Penelitian komunikasi kualitatif. Yogyakarta: LKiS.

Putra, M. (2020). Kurang efisiennya pembelajaran daring/e-learning.

Sardiman, A. M. (2011). Interaksi dan Motivasi Belajar Mengajar. Jakarta: Rajawali Press.

Sugiyono. (2015). Metode penelitian kombinasi (mix methods). Bandung: Alfabeta.

Sutopo. (2006). Metodologi penelitian kualitatif. Surakarta: UNS. 